\title{
Genetic Analysis of Eutypa Strains from California Supports the Presence of Two Pathogenic Species
}

\author{
Richard A. DeScenzo, Stacia R. Engel, German Gomez, Erik L. Jackson, Gary P. Munkvold, \\ Jennifer Weller, and Nancy A. Irelan
}

First, second, fourth, and seventh authors: Biotechnology Research Group, E. \& J. Gallo Winery, Modesto, CA 95353; third author: Department of Immunology, University of Colorado Health Sciences Center, Denver 80262; fifth author; Department of Plant Pathology, Iowa State University, Ames 50011; and sixth author: National Center for Genome Resources, Santa Fe, NM 87505.

Accepted for publication 2 July 1999.

\begin{abstract}
DeScenzo, R. A., Engel, S. R., Gomez, G., Jackson, E. L., Munkvold, G. P., Weller, J., and Irelan, N. A. 1999. Genetic analysis of Eutypa strains from California supports the presence of two pathogenic species. Phytopathology 89:884-893.

Eutypa dieback is a perennial canker disease that adversely affects grape (Vitis vinifera) production throughout the world. The causal agent has been known as either Eutypa armeniacae or E. lata, and it has been unclear whether the two taxa are separate species. We analyzed 115 isolates of Eutypa and conspecific strains, including 106 from California, using amplified fragment length polymorphism (AFLP) and sequence analysis of the ribosomal DNA (rDNA) internal transcribed spacer (ITS) sequence.

of 0.34 , as calculated by the DICE coefficient (NTSYS-pc software). An unweighted pair-group method with arithmetic averages dendrogram revealed a genetically distinct (distance of 0.73 ) group of Eutypa strains from valley oak (Quercus lobata) and madrone (Arbutus menziesii) and a strain from grape. Analysis of rDNA ITS sequences strongly supported the genetically distinct cluster detected in the AFLP data. Combined data indicated the presence of two species of Eutypa (E. armeniacae and E. lata) in our sample population. However, both Eutypa species were capable of infecting native and cultivated hosts, suggesting the potential for native tree species to serve as inoculum sources for grape infection in California. Further investigations of E. armeniacae and E. lata would contribute to the development of a successful disease management strategy.
\end{abstract} Strains from cultivated plant species exhibited an average genetic distance
Eutypa dieback affects grape (Vitis vinifera) production throughout the world and poses a major economic threat to industries associated with grape production $(5,6,16,33,35,39)$. The causal agent was first described as Eutypa armeniacae Hansf. \& M.V. Carter (4,31, 32 ), but the species was later considered conspecific with $E$. lata (Pers.:Fr.) Tul. \& C. Tul. (46). Most recent publications (35-39,42, 44) refer to the causal agent as E. lata, but some authors (14-16,30) continue to support the separation of the two species. For clarity, in our paper, E. lata refers to the species as circumscribed by Rappaz (46), and E. lata sensu stricto refers to the species as it was recognized prior to 1987 (with E. armeniacae as a separate species). Yield losses due to Eutypa dieback range from 19 to $50 \%$ in vines expressing moderate symptoms and from 62 to $94 \%$ in vines expressing severe symptoms $(24,35)$. Eventually, infected vines must be removed and the vineyard replanted or disease-free scions grafted onto existing, healthy rootstock. Current methods of control include pruning late in the dormant season and treatment of pruning wounds with the benzimidazole fungicide benomyl $(33,36,37,45,54,58)$. Although partially effective, these methods are difficult to implement in large commercial vineyards and seldom provide complete protection.

Infections occur primarily through pruning wounds, and the fungus colonizes plant vascular tissue, resulting in a chronic, lethal condition (10). Canker formation, vascular occlusion, and production of phytotoxic compounds result in yield reduction and, eventually, vine death $(10,35,38)$. Previous reports suggest Eutypa infections occur only after ascospore deposition on a susceptible wound (4).

Corresponding author: R. A. DeScenzo

E-mail address: rich.descenzo@ejgallo.com

Publication no. P-1999-0824-01R

(C) 1999 The American Phytopathological Society
There is some evidence, however, that conidia can be infectious under optimal conditions (25). Epidemiological studies of the spatial patterns of diseased vines also suggest that disease spread is not solely due to ascospore dispersal (22).

E. lata has a wide host range, including at least 60 species (6), and causes dieback diseases on grape and other cultivated hosts, primarily apricot (4). Isolates obtained from many genera (e.g., Ribes, Juglans, Prunus, Malus, and Salix) can successfully colonize one or more host species. Previous studies on the pathogenicity of $E$. lata isolates derived from various host species indicate grape is a universal host $(5,38)$. Although $E$. lata exhibits a wide range of virulence toward grape (42), no reports have demonstrated high levels of resistance to $E$. lata in any grape species tested. However, Munkvold and Marois (39) observed differences in cultivar susceptibility to $E$. lata related to wound response characteristics.

Eutypa dieback is a potentially serious problem in mature vineyards throughout California $(35,37,39)$. As a result, the regional sources of inoculum and genetic structure of local Eutypa populations are of major interest. Although there is a high incidence of disease reported in the Central Valley of California, mature stroma (i.e., containing perithecia) are difficult to find on grape vines in the region (38). This, in combination with the ability of E. lata to infect multiple host species, suggests the potential for nongrape host species to serve as inoculum sources for Central Valley vineyards. Apricot, cherry, almond, walnut, olive, and peach are important agricultural crops in the Central Valley and are all potential sources of $E$. lata inoculum $(6,38)$. Although $E$. lata has a wide host range, there are no reports of pathotype identification based on genetic analysis. However, it is difficult to distinguish between species of Eutypa based on morphology, and it is possible that the wide host range could be attributed to more than a single Eutypa species (14-16). To improve management of Eutypa dieback in California vineyards, it is necessary to (i) identify potential inoculum sources 
in native and cultivated plant species, (ii) determine whether there are pathotypes or multiple species of Eutypa, and (iii) elucidate the level of genetic diversity in the California population of Eutypa.

In recent years, numerous investigators, using biochemical and genetic techniques, have studied the population structure of phytopathogenic fungi. These techniques have included isozyme analysis $(13,18,44,60)$, fatty acid profiling (12), sequencing of the ribosomal DNA (rDNA) internal transcribed spacer (ITS) sequence $(1,3,34,40,47)$, restriction fragment length polymorphism $(13,18,27$, $55,57)$, variable number tandem repeat $(9,19)$, polymerase chain reaction (PCR)-based random amplified polymorphic DNA (RAPD) $(8,17,43,44,51)$, and PCR-based amplified fragment length polymorphism (AFLP) $(17,28,29,41)$. PCR-based techniques are advantageous in that they are amenable to high throughput and require small amounts of template DNA $(56,59)$. In the current study, we elected to use AFLP, because it is a robust, reproducible technique that generally produces a higher number of easily scored fragments than RAPD $(17,23)$. In addition, we examined the rDNA ITS sequence in a subsample of isolates to elucidate genetic relationships at the DNA sequence level and to verify the identity of genetically distinct isolates, as determined by AFLP analysis.

Our investigation represents an initial survey of genetic diversity among Eutypa isolates from several $V$. vinifera production regions in California. This analysis should enable us to identify putative pathotypes or species in Eutypa isolates from several cultivated and wild host species. Additionally, we hope to gain insight into the epidemiology of Eutypa dieback in terms of inoculum sources and spread of the pathogen.

\section{MATERIALS AND METHODS}

Fungal strains. The isolates used were selected based on host species and geographic origin. AFLP analysis was performed on 112 strains of E. lata and 3 isolates of Libertella viticola (the anamorph of E. lata) from 10 host species (Table 1). Of the 115 isolates, 106 originated in California, 4 in Italy, 2 in Michigan, and 1 each in New York, Australia, and South Africa. For genetic comparison, one isolate of Eutypella vitis, another species in the family Diatrypaceae, was included in the analysis. All isolates used have been deposited in the E. \& J. Gallo Winery Culture Collection (Modesto, CA). Initial identification of E. lata isolates was based on comparison of the morphology of the anamorph (or teleomorph when available) with published descriptions (14-16).

DNA extraction. Isolates were grown for 3 weeks prior to harvest in $30 \mathrm{ml}$ of liquid medium (2\% malt extract and $0.2 \%$ yeast extract) in 125-ml Erlenmeyer flasks at room temperature (20 to $25^{\circ} \mathrm{C}$ ) with light. Mycelial mats were collected by vacuum-filtration on Whatman No. 54 filter paper (Whatman Paper, Maidstone, England) and dried for $10 \mathrm{~min}$ by placing the mats between paper towels. Dried mats were ground to a fine powder in liquid nitrogen with a mortar and pestle.

DNA was extracted according to a modification of the method of Dellaporta et al. (7). Extraction buffer (100 mM Tris, $\mathrm{pH} 8.0$; $50 \mathrm{mM}$ EDTA, pH 8.0; $500 \mathrm{mM} \mathrm{NaCl} ; 1.25 \%$ sodium dodecyl sulfate; $10 \mathrm{mM} \beta$-mercaptoethanol) at $65^{\circ} \mathrm{C}$ was added to mycelial mats at $2 \mathrm{ml} / \mathrm{g}$, and the mixture was stored at $-20^{\circ} \mathrm{C}$ until all isolates were ready for processing. Mixtures were incubated at $65^{\circ} \mathrm{C}$ for $30 \mathrm{~min}$, followed by the addition of $40 \%$ (vol/vol) $5 \mathrm{M}$ potassium acetate. Mixtures were stored at $-20^{\circ} \mathrm{C}$ for $30 \mathrm{~min}$ followed by centrifugation at $25,000 \times g$ for $20 \mathrm{~min}$. Supernatant was filtered through Miracloth (CalBiochem-Behring Corp., La Jolla, CA), mixed with 0.58 volumes of ice-cold isopropanol, and placed at $-20^{\circ} \mathrm{C}$ for $30 \mathrm{~min}$. The resulting DNA precipitate was either spooled out on glass hooks or pelleted by centrifugation at $20,000 \times g$ for $15 \mathrm{~min}$. DNA was dried lightly prior to resuspension in $0.75 \mathrm{ml}$ of TE (10 mM Tris, $1 \mathrm{mM}$ EDTA, pH 8.0) and transfer to a $1.7-\mathrm{ml}$ microcentrifuge tube. DNA was extracted once with phenol-chloroform-isoamyl alcohol (25:24:1, vol/vol/vol) followed by two extrac- tions with chloroform-isoamyl alcohol (24:1, vol/vol). Polysaccharides were removed by adding an equal volume of $5 \mathrm{M} \mathrm{NaCl}$, mixing well, and precipitating DNA with 2 volumes of $100 \%$ ice-cold ethanol. DNA was spooled out with a glass hook, dried, and resuspended in $500 \mu \mathrm{l}$ of $\mathrm{ddH}_{2} \mathrm{O}$. DNA was precipitated with 0.1 volumes of $7.5 \mathrm{M} \mathrm{NH}_{4} \mathrm{Ac}$ and $1.1 \mathrm{ml}$ of $100 \%$ ice-cold ethanol. DNA was quantified with a minifluorometer (TKO-100, Hoefer Scientific Instruments, San Francisco) following the manufacturer's instructions.

DNA sequencing. PCR was run on a PCR system (GeneAmp 9600, Perkin-Elmer Cetus Corp., Norwalk, CT). Target sequences were amplified from genomic DNA in 50- $\mu$ l reactions containing $5 \mu \mathrm{l}$ of GeneAmp 10× PCR buffer, $8 \mu \mathrm{l}$ of $1.25 \mathrm{mM}$ GeneAmp dNTPs, $0.25 \mu \mathrm{l}$ of AmpliTaq DNA polymerase (Perkin-Elmer, Applied Biosystems Division, Foster City, CA), $0.25 \mu$ each of ITS5 and ITS4 primers (58), and $36.25 \mu \mathrm{l}$ of $\mathrm{dH}_{2} \mathrm{O}$. Samples were processed through 30 cycles of $94^{\circ} \mathrm{C}$ for $30 \mathrm{~s}, 58^{\circ} \mathrm{C}$ for $40 \mathrm{~s}$, and $72^{\circ} \mathrm{C}$ for $2 \mathrm{~min}$, followed by a final elongation step of $72^{\circ} \mathrm{C}$ for $10 \mathrm{~min}$. PCR products were purified with PCR purification kits (QIAquick, Qiagen Ltd., Chatsworth, CA) to remove any excess primers, nucleotides, and polymerases. Purified PCR products $(5 \mu \mathrm{l})$ were run on a $1.2 \%$ agarose gel with $5 \mu \mathrm{l}$ of pGEM-3Zf(+) (Applied Biosystems) doublestranded DNA control template $(0.2 \mathrm{~g} /$ liter $)$ to estimate concentrations. All samples were sequenced directly from purified PCR products. Sequencing was performed on an automated DNA sequencer (ABI PRISM 377) using ABI PRISM dye terminator cyclesequencing ready-reaction kits (Applied Biosystems). Cycle-sequencing products were purified over spin columns (Centri-Sep, Princeton Separations Inc., Adelphia, NJ) to remove excess primers, dye-labeled terminators, nucleotides, and polymerases. Samples were dried in a SpeedVac (Savant Instruments, Holbrook, NY) and run on the automated sequencer.

AFLP analysis. All reaction parameters and thermocycler profiles were performed following the manufacturers' instructions. PCR reactions were run on a PCR system (GeneAmp 9600). A single reaction was used to restrict DNA with EcoRI and $M s e I$ and ligate adapters, followed by preselective amplification using the AFLP ligation kit (Applied Biosystems). Preselective amplification products were verified on agarose gels followed by selective amplification using the AFLP selective amplification kit (Applied Biosystems). Ten pairs of two selective-base primers (MseI-EcoRI) were used in the analysis: CA-AT, CA-AC, CA-AA, CC-AC, CC-AA, CG-AC, CG-AG, CG-AA, CT-AC, and CT-AA. Approximately $0.5 \mu \mathrm{l}$ of selective amplification product was added to $1.5 \mu \mathrm{l}$ of loading buffer (1.0 $\mu \mathrm{l}$ of formamide, $0.45 \mu \mathrm{l}$ of loading dye, $0.5 \mu \mathrm{l}$ of GS $500 \mathrm{ROX}$ standard [Applied Biosystems]), denatured for $3 \mathrm{~min}$ at $90^{\circ} \mathrm{C}$, and placed on ice.

Gel electrophoresis. Samples were analyzed on an ABI PRISM 377 automated fluorescent sequencer. Approximately $1.5 \mu \mathrm{l}$ of denatured sample was loaded onto a 36-cm well-to-read gel containing 5\% LongRanger (FMC BioProducts, Rockland, ME) and $7 \mathrm{M}$ urea in $1 \times$ TBE (0.089 M Tris, $0.089 \mathrm{M}$ boric acid, $0.002 \mathrm{M}$ EDTA, $\mathrm{pH}$ 8.45). AFLP gels used 36-lane square-tooth combs and were run at $2,650 \mathrm{~V}$ for $3.5 \mathrm{~h}$ with $1 \times \mathrm{TBE}$ buffer. Scans were collected from 1,000 to 8,500 data points. Sequencing gels used 36-lane squaretooth combs and were run at $1,680 \mathrm{~V}$ for $9 \mathrm{~h}$ with $1 \times \mathrm{TBE}$ buffer.

AFLP data analysis. AFLP analysis is a powerful tool for detecting DNA polymorphisms in genetically similar organisms. Fluorescent AFLP analysis is highly sensitive to genetic variation due to computer-generated gel files and data analysis. Low copy number DNA fragments in the genome are detectable by fluorescent AFLP and are reproducible and informative. However, the ABI PRISM 377 system for fluorescent AFLP analysis is very sensitive to artifactual errors due to sample preparation, gel electrophoresis conditions, and data analysis methods (R. DeScenzo, unpublished data). To maximize the information extracted from each primer pair, it is imperative to accurately detect the presence or absence of all fragments. To assure accuracy in AFLP data analysis, it is critical to 
normalize lanes within gels to each other, as well as to lanes from the other gels used in the study. Identifying a target number of bands (TNB) for each primer pair and adjusting analysis parameters so a similar number of bands is detected for each sample effectively normalizes all samples. In our experience, this process eliminates the majority of artifactual variations initially observed with fluorescent AFLP.

Data were acquired using GeneScan version 2.1 (Applied Biosystems). Lanes were tracked manually and extracted. Initial analysis parameters were set as: analysis range of 1,400 to 8,000 scans based on migration of 50- and 500-base GS 500 ROX standards; data processing, baseline and multicomponent options, and smooth options light checked; size call range from 50 to 500; local southern method for size calling method; split peak correction at none; and peak detection at 100 for red and the two primer colors not used, at 15 for the primer color used on the gel, and minimum peak half width at 5 points. After initial analysis, sample files were imported into GenoTyper version 2.0 (Applied Biosystems), and scale factors were calculated for each sample file. Scale factors were used to assign dye color-specific peak amplitude thresholds (PAT) for each

TABLE 1. Fungal isolates used in amplified fragment length polymorphism and rDNA internal transcribed spacer (ITS) sequence analysis

\begin{tabular}{|c|c|c|c|c|c|}
\hline $\mathrm{ID}^{\mathrm{a}}$ & Origin $^{b}$ & Fungal species ${ }^{\mathrm{c}}$ & Host & Source & Origin $^{\mathrm{d}}$ \\
\hline $\mathrm{E} 001 *$ & Australia & Eutypa armeniacae & Apricot & ATCC 28120 & Unknown \\
\hline $\mathrm{E} 002 *$ & South Africa & Eutypa armeniacae & Apricot & ATCC 28900 & Unknown \\
\hline $\mathrm{E} 050 *$ & Illinois & Eutypella vitis & Grape & ATCC 64171 & Unknown \\
\hline $\mathrm{E} 100 *$ & Yolo Co. & Eutypa lata & Almond & G. Munkvold & Stromata \\
\hline E101* & Sonoma Co. & E. lata & Blueberry & D. Gubler & Wood \\
\hline E102* & Solano Co. & E. lata & Kiwi & D. Gubler & Wood \\
\hline E103* & San Joaquin Co. & E. lata & Bing cherry & G. Munkvold & Stromata \\
\hline E104* & Yolo Co. & E. lata & Bing cherry & G. Munkvold & Wood \\
\hline E105* & Yolo Co. & E. lata & Apricot & G. Munkvold & Stromata \\
\hline E106* & Solano Co. & E. lata & Apricot & G. Munkvold & Stromata \\
\hline E107* & Merced Co. & E. lata & Grape & G. Munkvold & Wood 1 \\
\hline E108* & Merced Co. & E. lata & Grape & G. Munkvold & Wood \\
\hline E109* & Merced Co. & E. lata & Grape & G. Munkvold & Wood \\
\hline E110* & Sacramento Co. & E. lata & Grape & G. Munkvold & Wood \\
\hline E111* & Sacramento Co. & E. lata & Grape & G. Munkvold & Wood \\
\hline $\mathrm{E} 112 *$ & Sacramento Co. & E. lata & Grape & G. Munkvold & Wood \\
\hline E113* & Napa Co. & E. lata & Grape & G. Munkvold & Wood \\
\hline E114* & Napa Co. & E. lata & Grape & G. Munkvold & Wood \\
\hline E116* & Sonoma Co. & E. lata & Grape & G. Munkvold & Wood \\
\hline $\mathrm{E} 117 *$ & New York & E. lata & Grape & R. Pearson & Unknown \\
\hline E118* & Yolo Co. & E. lata & Grape & G. Munkvold & Stromata \\
\hline E119* & San Joaquin Co. & E. lata & Grape & G. Munkvold & Wood \\
\hline E120* & Sonoma Co. & E. lata & Grape & E. \& J. Gallo Winery & Wood 2 \\
\hline $\mathrm{E} 121 *$ & Sonoma Co. & E. lata & Grape & E. \& J. Gallo Winery & Wood 2 \\
\hline E122* & Sonoma Co. & E. lata & Grape & E. \& J. Gallo Winery & Wood 2 \\
\hline E123* & Michigan & E. lata & Grape & D. Ramsdell & Unknown \\
\hline E124* & Michigan & E. lata & Grape & D. Ramsdell & Unknown \\
\hline $\mathrm{E} 125^{*}$ & Italy & E. lata & Grape & S. Di Marco & Wood \\
\hline E126* & Merced Co. & E. lata & Grape & G. Munkvold & Wood 1 \\
\hline $\mathrm{E} 127 *$ & Merced Co. & E. lata & Grape & G. Munkvold & Wood 1 \\
\hline $\mathrm{E} 128 *$ & Lake Co. & E. lata & Grape & D. Rizzo & Wood \\
\hline E129 & Lake Co. & E. lata & Grape & D. Rizzo & Wood \\
\hline E134 & Suisun Co. & E. lata & Kiwi & D. Rizzo & Wood 3 \\
\hline E135 & Suisun Co. & E. lata & Kiwi & D. Rizzo & Wood 3 \\
\hline E176 & Stanislaus Co. & E. lata & Grape & E. \& J. Gallo Winery & Wood \\
\hline $\mathrm{E} 177 *$ & Sonoma Co. & E. lata & Valley oak ${ }^{\mathrm{e}}$ & E. \& J. Gallo Winery & Wood 4a \\
\hline $\mathrm{E} 178 *$ & Sonoma Co. & E. lata & Valley oak & E. \& J. Gallo Winery & Wood 4a \\
\hline E179* & Sonoma Co. & E. lata & Valley oak & E. \& J. Gallo Winery & Wood 4a \\
\hline E180* & Sonoma Co. & E. lata & Valley oak & E. \& J. Gallo Winery & Wood 4a \\
\hline E182 & Napa Co. & E. lata & Grape & E. \& J. Gallo Winery & Wood \\
\hline E183 & San Joaquin Co. & E. lata & Grape & E. \& J. Gallo Winery & Wood 5a \\
\hline E185 & San Joaquin Co. & E. lata & Grape & E. \& J. Gallo Winery & Wood 5a \\
\hline E186 & Mendocino Co. & E. lata & Grape & E. \& J. Gallo Winery & Wood 6a \\
\hline E187 & Mendocino Co. & E. lata & Grape & E. \& J. Gallo Winery & Wood 6a \\
\hline E188* & Stanislaus Co. & E. lata & Grape & E. \& J. Gallo Winery & Wood \\
\hline E189* & Madera Co. & E. lata & Grape & E. \& J. Gallo Winery & Wood 7a \\
\hline E190* & Madera Co. & E. lata & Grape & E. \& J. Gallo Winery & Wood 7a \\
\hline E191 & Madera Co. & E. lata & Grape & E. \& J. Gallo Winery & Wood 7 \\
\hline E192* & Mendocino Co. & E. lata & Grape & E. \& J. Gallo Winery & Wood \\
\hline E193 & Madera Co. & E. lata & Grape & E. \& J. Gallo Winery & Wood $7 b$ \\
\hline E194 & Madera Co. & E. lata & Grape & E. \& J. Gallo Winery & Wood $7 b$ \\
\hline E195 & Madera Co. & E. lata & Grape & E. \& J. Gallo Winery & Wood 7c \\
\hline
\end{tabular}

\footnotetext{
a $*$ indicates isolate was used in rDNA ITS region DNA sequence analysis.

${ }^{\mathrm{b}}$ Counties are in California.

c As originally identified.

d Wood followed by the same number indicates same vineyard or orchard; wood followed by the same letter indicates same vine or tree.

e Quercus lobata.

f Prunus sp.

g Arbutus menziesii.

h Ceanothus sp.
} 
lane in a gel. Analysis parameters were set (as above) for each lane based on the adjusted PAT. Lanes were reanalyzed, and the number of bands detected per lane was determined. The lane with the lowest assigned PAT was used to determine the TNB for each primer pair. PAT was adjusted, when necessary, in the other 35 lanes to detect TNB plus or minus three bands. The results from the gel analysis were exported into a text file containing all band information for each lane. Text files were reformatted for use with the AFLP program (W. Lamboy, Cornell University, Geneva, NY), which converted the text data into a binary format for further analysis. A band in one lane was scored as 1 for presence or 0 for absence. Analysis parameters for AFLP were set as: minimum peak size $=15$; minimum fragment size (base pairs) $=50$; maximum fragment size (base pairs) $=500$; interval length (base pairs) in which there can only be one fragment in a lane $=0.8$; and maximum difference in length between two fragments considered the same size $=0.4$.

The binary data files from 10 primer pairs were combined into a single file and formatted for NTSYS-pc version 2.02f (Exeter Biological Software, Setauket NY). Similarity was determined using the SIMQUAL module and DICE coefficient. A dendrogram was

TABLE 1. (continued from preceding page)

\begin{tabular}{|c|c|c|c|c|c|}
\hline $\mathrm{ID}^{\mathrm{a}}$ & Origin $^{b}$ & Fungal species ${ }^{c}$ & Host & Source & Origin $^{\mathrm{d}}$ \\
\hline E196* & Madera Co. & E. lata & Grape & E. \& J. Gallo Winery & Wood 7c \\
\hline E197 & Madera Co. & E. lata & Grape & E. \& J. Gallo Winery & Wood 7c \\
\hline E198* & Madera Co. & E. lata & Grape & E. \& J. Gallo Winery & Wood 7c \\
\hline E199* & Madera Co. & E. lata & Grape & E. \& J. Gallo Winery & Wood 7d \\
\hline E200 & Madera Co. & E. lata & Grape & E. \& J. Gallo Winery & Wood 7d \\
\hline E201* & Sonoma Co. & E. lata & Grape & E. \& J. Gallo Winery & Wood 8 \\
\hline $\mathrm{E} 202 *$ & Sonoma Co. & E. lata & Grape & E. \& J. Gallo Winery & Wood 8 \\
\hline E203* & Sonoma Co. & E. lata & Grape & E. \& J. Gallo Winery & Wood 8a \\
\hline E204 & Sonoma Co. & E. lata & Grape & E. \& J. Gallo Winery & Wood $8 b$ \\
\hline E205* & Fresno Co. & E. lata & Grape & E. \& J. Gallo Winery & Wood \\
\hline E206* & San Joaquin Co. & E. lata & Grape & E. \& J. Gallo Winery & Wood \\
\hline E207 & Yolo Co. & E. lata & Grape & E. \& J. Gallo Winery & Wood 9a \\
\hline E208* & Solano Co. & E. lata & Grape & E. \& J. Gallo Winery & Wood 10 \\
\hline E209* & Solano Co. & E. lata & Grape & E. \& J. Gallo Winery & Wood 10 \\
\hline E210 & Sonoma Co. & E. lata & Grape & E. \& J. Gallo Winery & Wood 8a \\
\hline E211 & Sonoma Co. & E. lata & Grape & E. \& J. Gallo Winery & Wood 8a \\
\hline E212 & Sonoma Co. & E. lata & Grape & E. \& J. Gallo Winery & Wood 8a \\
\hline E213 & Sonoma Co. & E. lata & Grape & E. \& J. Gallo Winery & Wood 8a \\
\hline $\mathrm{E} 214 *$ & Sonoma Co. & E. lata & Grape & E. \& J. Gallo Winery & Wood 8c \\
\hline $\mathrm{E} 215^{*}$ & Sonoma Co. & E. lata & Grape & E. \& J. Gallo Winery & Wood 8c \\
\hline E216 & Sonoma Co. & E. lata & Grape & E. \& J. Gallo Winery & Wood 8b \\
\hline $\mathrm{E} 217 *$ & Merced Co. & E. lata & Grape & E. \& J. Gallo Winery & Wood \\
\hline E218 & Sonoma Co. & E. lata & Grape & E. \& J. Gallo Winery & Wood 11a \\
\hline E219 & Sonoma Co. & E. lata & Grape & E. \& J. Gallo Winery & Wood 11a \\
\hline E220 & San Joaquin Co. & E. lata & Grape & E. \& J. Gallo Winery & Wood \\
\hline E221 & Yolo Co. & E. lata & Grape & E. \& J. Gallo Winery & Wood 9a \\
\hline E222 & Yolo Co. & E. lata & Grape & E. \& J. Gallo Winery & Wood 9a \\
\hline E224 & Solano Co. & E. lata & Grape & E. \& J. Gallo Winery & Wood 10a \\
\hline E225 & Yolo Co. & E. lata & Grape & E. \& J. Gallo Winery & Wood 9b \\
\hline E226 & Stanislaus Co. & E. lata & Grape & E. \& J. Gallo Winery & Wood \\
\hline $\mathrm{E} 227 *$ & Madera Co. & E. lata & Grape & E. \& J. Gallo Winery & Wood 7d \\
\hline E228 & Madera Co. & E. lata & Grape & E. \& J. Gallo Winery & Wood 7d \\
\hline E229 & Sonoma Co. & E. lata & Grape & E. \& J. Gallo Winery & Wood 8c \\
\hline $\mathrm{E} 230 *$ & Sonoma Co. & E. lata & Cherry ${ }^{\mathrm{f}}$ & E. \& J. Gallo Winery & Wood 8 \\
\hline E231 & Merced Co. & E. lata & Grape & E. \& J. Gallo Winery & Wood \\
\hline E232 & Sonoma Co. & E. lata & Grape & E. \& J. Gallo Winery & Wood 8c \\
\hline E233 & Fresno Co. & E. lata & Grape & E. \& J. Gallo Winery & Wood \\
\hline E234 & Yolo Co. & E. lata & Grape & E. \& J. Gallo Winery & Wood 9b \\
\hline E235 & Yolo Co. & E. lata & Grape & E. \& J. Gallo Winery & Wood 9a \\
\hline E236 & San Joaquin Co. & E. lata & Grape & E. \& J. Gallo Winery & Wood $12 \mathrm{a}$ \\
\hline E237 & San Joaquin Co. & E. lata & Grape & E. \& J. Gallo Winery & Wood $12 \mathrm{a}$ \\
\hline E238 & San Joaquin Co. & E. lata & Grape & E. \& J. Gallo Winery & Wood $12 \mathrm{a}$ \\
\hline E239 & San Joaquin Co. & E. lata & Grape & E. \& J. Gallo Winery & Wood 12 \\
\hline E240 & Yolo Co. & E. lata & Grape & E. \& J. Gallo Winery & Wood 9a \\
\hline E241 & El Dorado Co. & E. lata & Grape & E. \& J. Gallo Winery & Wood $13 a$ \\
\hline E242 & El Dorado Co. & E. lata & Grape & E. \& J. Gallo Winery & Wood $13 a$ \\
\hline $\mathrm{E} 243^{*}$ & El Dorado Co. & E. lata & Grape & E. \& J. Gallo Winery & Wood $13 b$ \\
\hline E244 & El Dorado Co. & E. lata & Grape & E. \& J. Gallo Winery & Wood $13 b$ \\
\hline E245 & El Dorado Co. & E. lata & Grape & E. \& J. Gallo Winery & Wood $13 \mathrm{c}$ \\
\hline E246 & El Dorado Co. & E. lata & Grape & E. \& J. Gallo Winery & Wood $13 \mathrm{c}$ \\
\hline E247* & El Dorado Co. & E. lata & Madrone ${ }^{g}$ & E. \& J. Gallo Winery & Wood $13 d$ \\
\hline E248 & El Dorado Co. & E. lata & Buckthorn ${ }^{\mathrm{h}}$ & E. \& J. Gallo Winery & Wood $13 \mathrm{e}$ \\
\hline E249* & El Dorado Co. & E. lata & Buckthorn & E. \& J. Gallo Winery & Wood $13 \mathrm{e}$ \\
\hline $\mathrm{E} 250 *$ & El Dorado Co. & E. lata & Buckthorn & E. \& J. Gallo Winery & Wood $13 \mathrm{e}$ \\
\hline $\mathrm{E} 251 *$ & El Dorado Co. & E. lata & Grape & E. \& J. Gallo Winery & Wood $13 \mathrm{f}$ \\
\hline $\mathrm{E} 252 *$ & El Dorado Co. & E. lata & Madrone & E. \& J. Gallo Winery & Wood $13 \mathrm{~d}$ \\
\hline $\mathrm{E} 253^{*}$ & El Dorado Co. & E. lata & Madrone & E. \& J. Gallo Winery & Wood $13 \mathrm{~d}$ \\
\hline $\mathrm{E} 254 *$ & El Dorado Co. & E. lata & Grape & E. \& J. Gallo Winery & Wood $13 \mathrm{f}$ \\
\hline $\mathrm{E} 255^{*}$ & San Luis Obispo Co. & E. lata & Grape & E. \& J. Gallo Winery & Wood 14 \\
\hline $\mathrm{E} 256^{*}$ & San Luis Obispo Co. & E. lata & Grape & E. \& J. Gallo Winery & Wood 14 \\
\hline L001* & Italy & Libertella viticola & Grape & S. DiMarco & Wood \\
\hline L002* & Italy & L. viticola & Grape & S. DiMarco & Wood \\
\hline L003* & Italy & L. viticola & Grape & S. DiMarco & Wood \\
\hline
\end{tabular}


constructed using the unweighted pair-group method with arithmetic averages (UPGMA) in the SAHN module. Additional analysis was performed on a subset of 67 isolates with the combined data from 10 primer pairs for comparison with ITS sequence data. In addition, DICE similarity was calculated for both the entire data set, as well as the subset, and for each primer pair. Pearson product moment correlation coefficient $(r)$ was calculated between individual DICEbased distance matrices for each primer pair to compare the ability of different AFLP primer pairs to detect genetic diversity. In addition, the $r$ value can be used as an indicator of genome coverage. A high $r$ value among a set of primers suggests the selected primers amplify similar areas of the genome.

DNA sequence analysis. Sequence data were imported into Sequence Navigator version 1.0.1 (Applied Biosystems), in which forward and reverse reads were aligned. CLUSTAL W (53) was used for multiple alignments, sequences were transferred into a PAUP version 4.0b1 (Sinauer Associates Inc., Sunderland, MA) file, and alignment was verified visually.

Tamura-Nei (52) distances for each spacer sequence were compared to determine whether spacers diverged at different rates. The spacer sequences were not analyzed separately because they diverged at the same rate (discussed below) and the individual DNA fragments were too short to recover a meaningful phylogeny $(2,48)$.

PAUP software was used for all sequence analyses. Heuristic (treebisection and reconnection) search algorithms were used because the large number of isolates precluded exhaustive searches. Each nucleotide was treated as an unordered character with four alternative states, and gaps were treated as missing characters. Phylogenetic hypotheses were generated for the DNA sequence data under the principle of maximum parsimony with 10 random addition sequences with equally weighted characters. Support for internal nodes was assessed by bootstrapping (11) with 500 replicates. To evaluate the sensitivity of tree topology to the algorithm used, trees also were generated for the DNA sequence data by the neighbor-joining algorithm (49) with both Kimura-2 parameter (26) and Tamura-Nei (52) distance measures.

Somatic compatibility analysis. Isolates of $E$. lata were grown in $100 \times 15-\mathrm{mm}$ petri plates on potato dextrose agar (PDA) (Difco Laboratories, Detroit). Agar plugs (5-mm diameter) containing mycelia from the colony margins were paired on fresh PDA plates for somatic compatibility testing. plates were incubated at $25^{\circ} \mathrm{C}$ in the

TABLE 2. Target number of bands and number of band classes observed in Eutypa lata for individual amplified fragment length polymorphism primer pairs

\begin{tabular}{lcc}
\hline $\begin{array}{l}\text { Primer pair } \\
(M s e I-E c o \text { RI })\end{array}$ & Target no. of bands & No. of band classes \\
\hline CA-AA & 71 & 319 \\
CA-AC & 45 & 303 \\
CA-AT & 70 & 339 \\
CC-AA & 76 & 323 \\
CC-AC & 52 & 324 \\
CG-AA & 60 & 305 \\
CG-AC & 35 & 300 \\
CG-AG & 55 & 313 \\
CT-AA & 70 & 299 \\
CT-AC & 50 & 328 \\
\hline
\end{tabular}

dark for 6 weeks. Multiple isolates from the same vine were tested against each other and self-paired. In addition, selected isolates from different locations were paired against each other. Plates were scored for compatibility reactions: strong $=$ definite barrage reaction with an easily visible, dark, depressed region; weak = clear area between two isolates devoid of mycelia; and no reaction. All pairings were repeated at least three times.

\section{RESULTS}

AFLP analysis. Analysis of fungal DNA was reproducible when selective amplification was repeated on the same set of preselective amplification products. Artifactual variation in reproducibility was observed most often when DNA from different isolations was examined. Additional artifacts also can be introduced, to a lesser extent, during the restriction-ligation reaction step (R. DeScenzo, unpublished data).

Initial data collection and formatting were performed using GeneScan version 2.1. Individual analysis parameter files were configured for each primer-lane combination to achieve the predetermined TNB. The TNB for the 10 primer combinations varied from 35 to 76 bands per lane (Table 2). Conversion of GeneScan data to a binary format using the AFLP program yielded a different number of band classes for each primer pair (Table 2). A total of 3,153 band positions was observed for the 10 primer pairs. There were 137 monomorphic band positions, 790 autapomorphic band positions, and 2,226 polymorphic band positions. Similarity matrices generated from individual primer pairs were compared using the Pearson product moment correlation. Correlation coefficients $(r)$ ranged from 0.58 to 0.94 (Table 3). Primer pair CT-AC had the lowest $r$ value when paired with other primers. A low correlation coefficient indicated the two primer pairs amplified markers from genetically different or specific regions of the genome. A high level of correlation between primer pairs indicated the AFLP markers either were from genetically similar regions of the genome or widely distributed throughout the genome. The overall high $r$ values observed between most of the primer pairs used in this study suggest the AFLP markers are probably widely distributed throughout the genome.

The DICE similarity coefficient was calculated from a total of 365,748 data points. A dendrogram was generated using the genetic similarity matrix for the 1 Eutypella vitis strain and 115 Eutypa strains. The matrix was computed using the combined AFLP data from 10 primer-pair data sets. The dendrogram consisted of one large cluster (Fig. 1, group A1) and one small cluster (Fig. 1, group B). Group B consists of four strains from valley oak (Quercus lobata), three strains from madrone (Arbutus menziesii), and one strain from grape. The strains were separated from the remaining 107 isolates by a genetic distance of 0.73 . Group A1 consisted primarily of one cluster containing 104 strains at an overall genetic distance of $\approx 0.45$. The genetic distance of the remaining three Eutypa isolates (Fig. 1, group A2), from California, Michigan, and New York, and the Eutypella vitis isolate ranged from 0.68 to 0.62 . The three A2 Eutypa strains may represent an intermediate genotype between the isolates from groups A1 and B. Within group A1, individual isolates from the same vineyard in California often clustered together. However, there was no evidence of clustering based on

TABLE 3. Correlation values ( $r$ ) for DICE similarity matrices between individual primer pairs (MseI-EcoRI) used to analyze Eutypa lata

\begin{tabular}{|c|c|c|c|c|c|c|c|c|c|}
\hline & CA-AC & CA-AT & CC-AA & CC-AT & CG-AA & CG-AC & CG-AG & CT-AA & CT-AC \\
\hline CA-AA & 0.83 & 0.92 & 0.91 & 0.71 & 0.91 & 0.92 & 0.87 & 0.79 & 0.60 \\
\hline CA-AC & & 0.80 & 0.81 & 0.69 & 0.83 & 0.82 & 0.82 & 0.73 & 0.58 \\
\hline CA-AT & & & 0.94 & 0.76 & 0.93 & 0.90 & 0.86 & 0.81 & 0.64 \\
\hline CC-AA & & & & 0.72 & 0.93 & 0.89 & 0.87 & 0.81 & 0.64 \\
\hline CC-AC & & & & & 0.73 & 0.71 & 0.70 & 0.77 & 0.77 \\
\hline CG-AA & & & & & & 0.89 & 0.88 & 0.82 & 0.63 \\
\hline CG-AC & & & & & & & 0.85 & 0.77 & 0.58 \\
\hline CG-AG & & & & & & & & 0.75 & 0.59 \\
\hline CT-AA & & & & & & & & & 0.65 \\
\hline
\end{tabular}




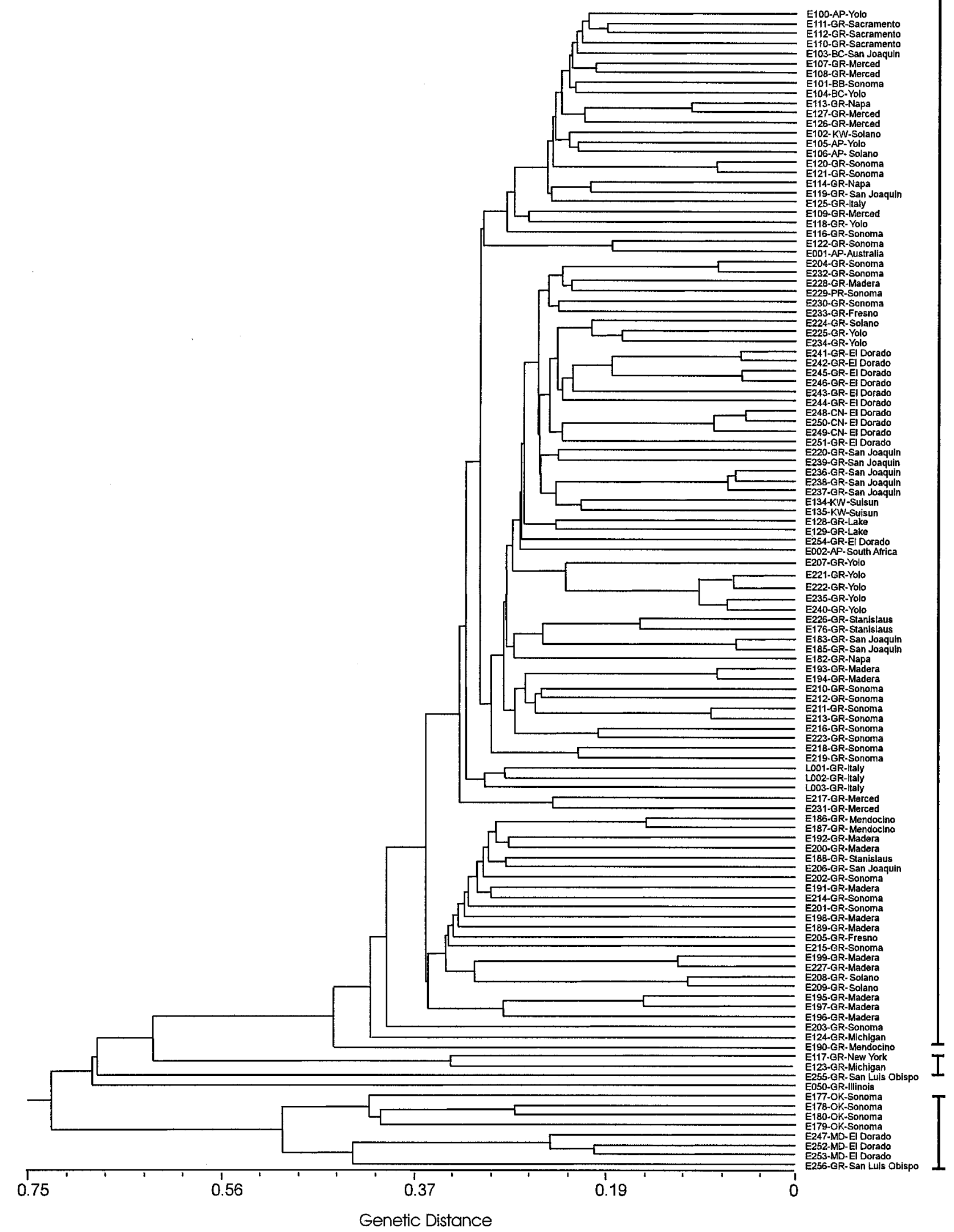

Fig. 1. Dendrogram generated by unweighted pair-group method with arithmetic average cluster analysis of amplified fragment length polymorphism (AFLP) data from 115 isolates of Eutypa lata and 1 isolate of Eutypella vitis. Genetic similarities were calculated using the DICE coefficient in the SIMQUAL module of NTSYS-pc (version 2.02f), based on 3,153 band positions observed for 10 AFLP primer pairs. Clusters are indicated by brackets. 
geographic area, i.e., North Coast, Central Valley, etc., with AFLP data. A tree produced by parsimony analysis of AFLP data (not shown) maintained topological congruency with the DICE-UPGMA analysis.
Strains from four native host species were examined. The three strains from madrone and four strains from valley oak were genetically distinct from the majority of Eutypa strains. Strains from native buckthorn (Ceanothus sp.) and cherry (Prunus sp.) were not

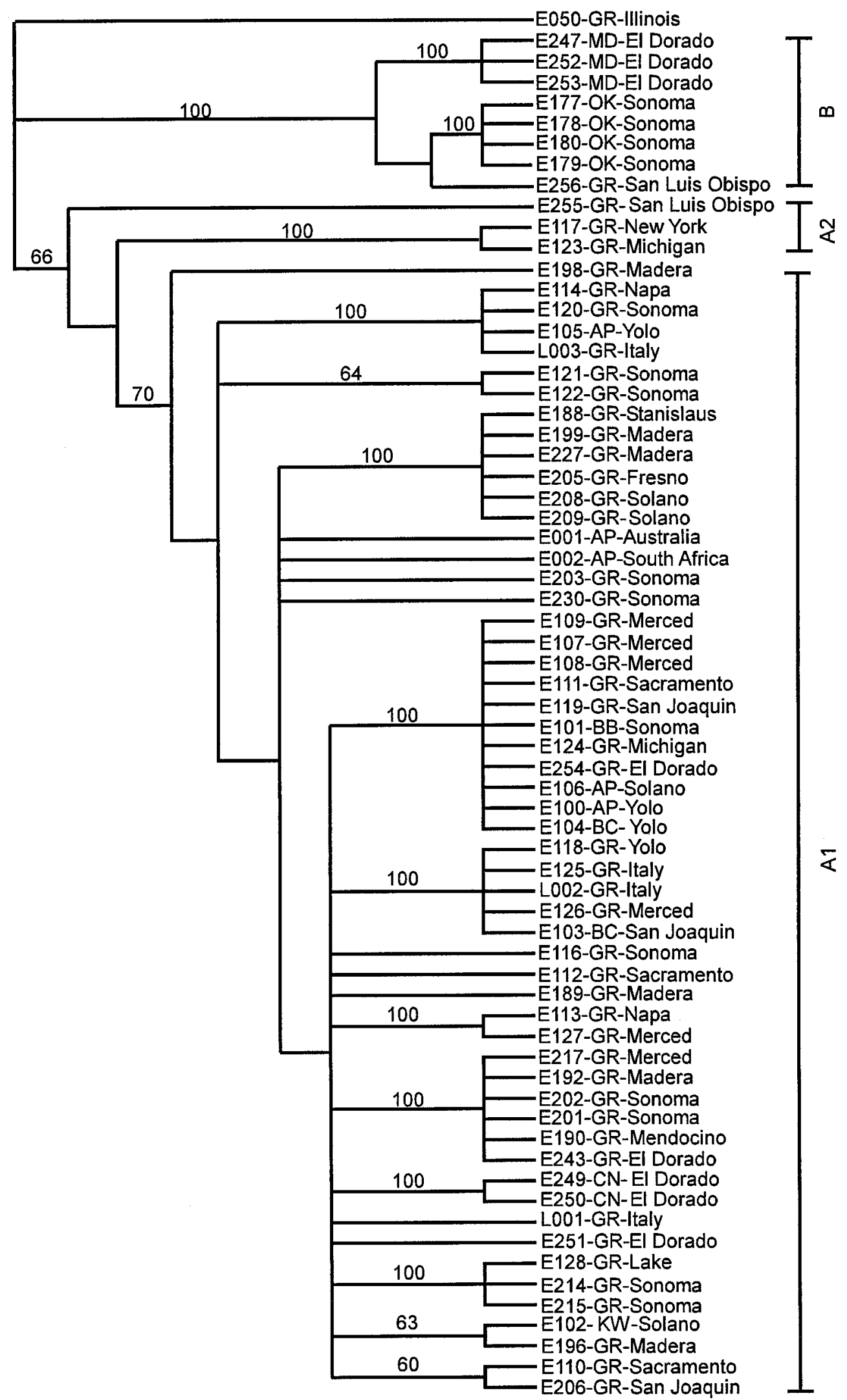

Fig. 2. Strict consensus of the six most parsimonious trees from analysis of nucleotide sequences spanning ITS1 and ITS2 for a subset of 66 Eutypa lata isolates and 1 Eutypella vitis isolate, showing support for internal nodes from bootstrap resampling ( $\geq 50$ shown) (length $=232$, consistency index $=0.8190$, retention index $=0.7730$ ). Clusters are indicated by brackets. 
genetically distinct from the majority of strains. Strains obtained from buckthorn were genetically closest to strains from grape in an adjacent vineyard. The isolate of Eutypella vitis was genetically distinct from group A1. However, it was more similar to groups A1 and A2 than to Eutypa isolates from group B.

ITS DNA sequence. The $5.8 \mathrm{~S}$ rDNA sequences were identical in all isolates and, therefore, were excluded from the analysis. The final DNA sequence data set included $380 \mathrm{bp}$ that spanned all of the ITS1 and ITS2 for the 1 Eutypella vitis isolate and 66 Eutypa isolates (Table 1). Many isolates had identical sequences. Therefore, the 66 Eutypa isolates exhibited only 30 sequence haplotypes; the most prevalent haplotype was present in 11 isolates from various geographic regions. The number of nucleotide differences among isolates of Eutypa ranged from 0 to 46, whereas the number of differences among Eutypella vitis and Eutypa isolates ranged from 50 to 67 . No difficulties were encountered in aligning the sequences. Variation in length was observed in both spacer sequences. ITS1 varied from 166 to $199 \mathrm{bp}$ (excluding gaps) in Eutypa compared with $169 \mathrm{bp}$ in Eutypella vitis, and ITS2 varied from 157 to $161 \mathrm{bp}$ (excluding gaps) in Eutypa compared with 167 bp in Eutypella vitis. Much of the variation in length in E. lata ITS1 was due to an 11-bp minisatellite tandemly repeated from one to four times from positions 66 to 109. The vast majority of isolates possessed three repeats. One isolate each exhibited one (E251), two (E117), and four (E189) repeats. Of the 380 total characters, 207 were constant, 94 were parsimony-uninformative, and 79 were parsimony-informative.

Pairwise comparisons of Tamura-Nei (52) genetic distances across all taxa for the two spacer sequences produced a strong correlation $(r=0.964)$, verifying that they diverged at essentially the same rate. However, in Eutypa, ITS1 is slightly more variable than ITS2, as has been found in other filamentous fungi (34). A parsimony analysis in which all nucleotide substitutions were weighted equally produced six equiparsimonious trees, the consensus of which is shown in Figure 2. Neighbor-joining analyses with both Kimura-2 parameter and Tamura-Nei (52) distance measures produced a topology with an overall arrangement of taxa congruent with that shown in Figure 2. The use of different distance measures with different underlying assumptions did not affect topology. There was strong support for a clade containing the Eutypa isolates from madrone and valley oak trees, as well as an anomalous isolate from grape, which agrees with the AFLP data (group A2). There was only weak to moderate support for the internal branches in the remainder of the tree, although there was strong support for several branches leading to terminal polytomies. Therefore, it may be more accurate to state that a basal polytomy exists between isolates that are more derived than the New York-Michigan clade.

Somatic compatibility. Isolates obtained from the same or adjacent vines were tested for somatic compatibility. There were no incompatible reactions observed in any of the self-pairings. All self-pairings resulted in mycelia that grew together with no visible barrage zone (Fig. 3). In all nonself-pairings, isolates exhibited somatic incompatibility and produced barrage zones ranging from weak to strong. A faint, yet definite, zone with sparse mycelia was observed in weak reactions. In contrast, barrage zones devoid of mycelia and with a visibly depressed, darkened region were observed in strong reactions (Fig. 3). In all pairings in which the genetic distance was less than 0.15 , a weak reaction was observed. In pairings in which the genetic distance was greater than 0.15 , a strong reaction was observed. In addition, pairings of any of the other selected strains with isolate E252 resulted in extensive mycelial lysis of the paired strain (Fig. 3D).

\section{DISCUSSION}

In this study, we observed a genetically distinct group of eight Eutypa isolates, group B, that consisted of three isolates from madrone, four isolates from valley oak, and one isolate from grape. The results support the concept of two species of Eutypa (E. lata sensu stricto and E. armeniacae), both capable of infecting grape and native hosts. Prior to 1987, E. armeniacae and other taxa were not synonymous with E. lata (30). McKemy et al. (30) initially suggested that E. armeniacae be retained as the name for pathogenic strains from diseased, cultivated hosts. Previous studies, based on morphology and pathogenicity (14-16), have suggested that the species predominantly found on grape and cultivated hosts (group A1) is E. armeniacae and is distinct from E. lata. The presence in group A1 of two strains obtained from the American Type Culture Collection (Manassas, VA) and originally identified as E. armeniacae supports this classification. We suggest that strains found predominantly on native hosts (group B) are probably E. lata sensu stricto.

Group B (E. lata sensu stricto) was more distant from group A1 (E. armeniacae, associated with cultivated hosts) than was Eutypella vitis, another member of the family Diatrypaceae. Group B was linked at a genetic distance of $\approx 0.73$ to the remaining 107 Eutypa strains. Group A2, consisting of three strains from grape, had a genetic distance ranging from 0.62 to 0.68 . The AFLP data, obtained using two selective-base primers, indicate that the Eutypella vitis isolate is more similar to group A1 than to group B, which suggests the strains from group B and A2 may represent different taxa than isolates from group A1.

Data from the 95 California strains collected from nonnative species indicate an overall high level of variability, with an average genetic distance of 0.34. Based on RAPD analysis, Péros et al. (44) reported a high level of genetic variation (Jaccard distance of $\approx 0.3$ ) in a sample population of $18 \mathrm{E}$. lata isolates representing 10 geographic regions in France. They reported polymorphisms between isolates from the same stroma and observed that isolates from different stromata generally were separated in cluster analysis. In a later study, Péros et al. (43) analyzed 32 polymorphic RAPD markers in a population of $55 \mathrm{E}$. lata isolates from a single vineyard in France. They detected the same high level of genetic variation within the vineyard, with an average Jaccard distance of 0.36 . These levels of genetic diversity are expected for a pathogen that is primarily dispersed by sexual spores. Péros et al. (43) were unable to correlate pathogenicity with a particular RAPD profile, and UPGMA analysis did not indicate any population substructure. They did observe one genetically distinct isolate in their study but were unable to positively identify it as E. lata based solely on RAPD and iso-

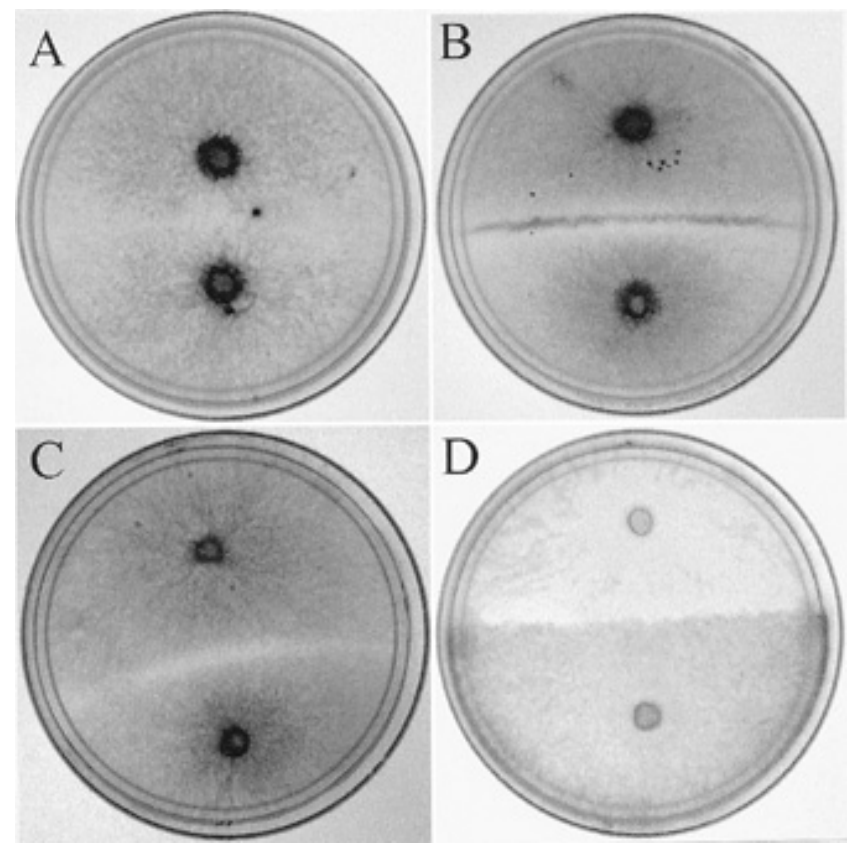

Fig. 3. Somatic compatibility interactions of Eutypa isolates from the same or adjacent vines. A, Self-pairing; B, strong reaction; C, weak reaction; and D, isolate E252 (bottom) caused mycelial lysis when paired with other isolates. 
zyme analyses. They suggested this isolate could be a variant of E. lata or a different species of Eutypa.

DNA sequence comparisons can provide a more direct assessment of genetic diversity and relationships and, therefore, can be extremely informative if the correct DNA region is analyzed. The rDNA ITS region is not highly conserved, and a number of studies have demonstrated its usefulness for resolving species and subspecies differences $(20,40,47)$. The ITS sequence data in our study strongly support the distinction, made also based on AFLP data, of the group B cluster (Fig. 2). The data also moderately support the separation of group A2 isolates from the other isolates. The three A2 isolates are more similar to group A1 than to group B based on ITS sequence data. The average transition to transversion ratio between groups A1 and A2 is 3.2, whereas the ratio between groups $\mathrm{A} 1$ and B is 0.89 . The balance of the tree, however, with the exception of branches leading to terminal polytomies, remains poorly resolved. Similar levels of ITS sequence identity have been observed in Acremonium and Epichloe (50), Armillaria (1), Sclerotium (3), Phomopsis (47), and Ganoderma (21). Therefore, the evolutionary rate of the ITS region, coupled with its short length in certain genera of fungi, appears to greatly impair its phylogenetic utility at the subspecific level, which reduces its effectiveness for ascertaining intraspecific relationships, while enhancing its usefulness for determining species boundaries.

Isolates from individual California counties in specific geographic regions, i.e., North Coast, Central Coast, and Central Valley, did not display greater similarity to each other than to isolates from different regions. However, genetic analyses indicated that isolates from a single vineyard or vine were more genetically similar to each other than to those from different locations. Somatic compatibility assays indicated the absence of clonal lineages among Eutypa isolates tested and, therefore, agreed with the genetic differences observed between isolates. Fungal somatic compatibility is regulated by several polymorphic loci, and only strains with identical alleles at each locus are compatible. Péros et al. (43) observed somatic incompatibility between all Eutypa isolates tested. Interestingly, they also observed one isolate that caused extensive mycelial lysis when paired with other isolates, similar to isolate E252 in our study.

The absence of somatic compatibility between isolates obtained from the same vine and their distinct AFLP fingerprints and ITS sequences can help verify multiple infections in a single vine. The similarity of same-vine isolates suggests a common source of inoculum. It is highly probable that ascospores from a single perithecium or stroma could produce multiple infections on a single vine. The AFLP and ITS sequence data corroborate this theory, because many of the isolates from single or adjacent vines formed discrete groups in cluster analysis.

The data presented here demonstrate the efficiency and applicability of AFLP and ITS sequence analyses for studying genetic similarity in Eutypa. In addition, our study represents the first step in using molecular tools to understand the genetic structure of Eutypa populations in California. The data suggest the presence of two species of Eutypa isolated from native and cultivated hosts. Three strains obtained from buckthorn (Ceanothus sp.) were not genetically distinct from E. armeniacae. The buckthorn bordered a vineyard, and strains from the buckthorn were genetically closest to E. armeniacae isolates from the adjacent vineyard, suggesting the potential for cultivated species to be sources of E. armeniacae inoculum for native species and vice versa. We were unable to determine whether the one isolate from grape in the E. lata sensu stricto group was pathogenic or saprophytic on grape. However, its isolation from a canker margin on a symptomatic plant suggests the isolate was pathogenic. This finding opens the possibility of native hosts acting as reservoirs for E. lata sensu stricto inoculum on grape.

The ability of either species to infect both grape and native hosts warrants additional investigations into native hosts as reservoirs for a genetically diverse source of Eutypa inoculum. The presence of two species that are both capable of infecting grape and the potential of unlimited inoculum from native hosts would complicate efforts to control this disease. A comprehensive understanding of the genetics of these pathogens would contribute to the development of a successful disease management strategy.

\section{ACKNOWLEDGMENTS}

We thank PE Applied Biosystems for providing AFLP kit components prior to the release of the Microbial AFLP Kit and for technical support. We thank D. Rizzo, S. DiMarco, and D. Ramsdell for providing isolates for the study; W. Lamboy for statistical consultation; and D. Fogle for assistance in identifying fungal isolates. We also thank T. Harrington for critical review of the manuscript.

\section{LITERATURE CITED}

1. Anderson, J. B., and Stasovski, E. 1992. Molecular phylogeny of northern hemisphere species of Armillaria. Mycologia 84:505-516.

2. Cao, Y., Adachi, J., Janke, A., Paabo, S., and Hasegawa, M. 1994. Phylogenetic relationships among eutherian orders estimated from inferred sequences of mitochondrial proteins: Instability of a tree based on a single gene. J. Mol. Evol. 39:519-527.

3. Carbone, I., and Kohn, L. M. 1993. Ribosomal DNA sequence divergence within internal transcribed spacer 1 of the Sclerotiniaceae. Mycologia 85: 415-427.

4. Carter, M. V. 1957. Eutypa armeniacae Hansf \& Carter, sp. nov., an airborne vascular pathogen of Prunus ameniaca L. in southern Australia. Aust. J. Bot. 5:212-235.

5. Carter, M. V., Bolay, A., English, H., and Rumbos, I. 1985. Variation in the pathogenicity of Eutypa lata (=E. armeniacae). Aust. J. Bot. 33:361-366.

6. Carter, M. V., Bolay, A., and Rappaz, F. 1983. An annotated host list and bibliography of Eutypa armeniacae. Rev. Plant Pathol. 62:251-258.

7. Dellaporta, S. L., Word, J., and Hicks, J. B. 1983. A plant DNA minipreparation. Version II. Plant Mol. Biol. Rep. 1:19-21.

8. Délye, C., Laigret, F., and Corio-Costet, M.-F. 1997. RAPD analysis provides insight into the biology and epidemiology of Uncinula necator. Phytopathology 87:670-677.

9. DeScenzo, R. A., and Harrington, T. C. 1994. Use of (CAT) 5 as a DNA fingerprinting probe for fungi. Phytopathology 84:534-540.

10. English, H., and Davis, J. R. 1978. Eutypa armeniacae in Apricot: Pathogenesis and induction of xylem soft rot. Hilgardia 46:193-204.

11. Felsenstein, J. 1985. Confidence limits on phylogenies: An approach using the bootstrap. Evolution 39:783-791.

12. Ferreira, J. H. S., and Augustyn, O. P. H. 1989. Differentiation between Eutypa lata and Cryptovalsa cf ampelina by means of cellular fatty acid analysis. S. Afr. J. Enol. Vitic. 10:18-22.

13. Forbes, G. A., Escobar, X. C., Ayala, C. C., Revelo, J., Ordonez, M. E., Fry, B. A., Doucett, K., and Fry, W. 1997. Population genetic structure of Phytophthora infestans in Ecuador. Phytopathology 87:375-380.

14. Glawe, D. A., and Rogers, J. D. 1982. Observations on the anamorphs of six species of Eutypa and Eutypella. Mycotaxon 14:334-346.

15. Glawe, D. A., and Rogers, J. D. 1984. Diatrypaceae in the Pacific Northwest. Mycotaxon 20:401-460.

16. Glawe, D., Skotland, C. B., and Moller, W. J. 1982. Isolation and identification of Eutypa armeniacae from diseased grapevine in Washington State. Mycotaxon 16:123-132.

17. González, M., Rodríguez, R., Zavala, M. E., Jacobo, J. L., Hernández, J. A., Acosta, J., Martínez, O., and Simpson, J. 1998. Characterization of Mexican isolates of Colletotrichum lindemuthianum by using differential cultivars and molecular markers. Phytopathology 88:292-299.

18. Goodwin, S. B., Spielman, L. J., Matuszak, J. M., Bergeron, S. N., and Fry, W. 1992. Clonal diversity and genetic differentiation of Phytophthora infestans populations in Northern and Central Mexico. Phytopathology 82: 955-961.

19. Harrington, T. C., Rizzo, D. M., DeScenzo, R. A., and Steimel, J. 1998. Genetic relationships among clones of Heterobasidion annosum in a pine forest. Pages 159-170 in: Root and Butt Rots of Forest Trees. 9th Int. Conf. Root Butt Rots. C. Delatour, J. J. Guillaumin, B. Lung-Escarmant, and B. Marcais, eds. INRA Editions, Paris, France.

20. Hillis, D. M., and Dixon, M. T. 1991. Ribosomal DNA: Molecular evolution and phylogenetic inference. Q. Rev. Biol. 66:411-453.

21. Hseu, R.-S., Wang, H.-H., Wang, H.-F., and Moncalvo, J.-M. 1996. Differentiation and grouping of isolates of the Ganoderma lucidum complex by random amplified polymorphic DNA-PCR compared with grouping on the basis of internal transcribed spacer sequences. Appl. Environ. Microbiol. 62:1354-1363.

22. Hughes, G., Munkvold, G. P., and Samita, S. 1998. Application of the logisticnormal-binomial distribution for analysis of Eutypa dieback disease inci- 
dence data. Int. J. Pest Manage. 44:35-42.

23. Janssen, P., Coopman, R., Huys, G., Swings, J., Bleeker, M., Vos, P., Zabeau, M., and Kersters, K. 1996. Evaluation of the DNA fingerprinting method AFLP as a new tool in bacterial taxonomy. Microbiology 142:1881-1893.

24. Johnson, D. A., and Lunden, J. D. 1985. Eutypa dieback in Washington State: Disease incidence and effect on yield. (Abstr.) Phytopathology 75:1370.

25. Ju, Y. M., Glawe, D. A., and Rogers, J. D. 1991. Conidial germination in Eutypa armeniacae and selected other species of Diatrypaceae: Implications for the systematics and biology of diatrypaceous fungi. Mycotaxon 41:311-320.

26. Kimura, M. 1980. A simple method for estimating evolutionary rate of base substitutions through comparative studies of nucleotide sequences. J. Mol. Evol. 16:111-120.

27. Koch, E., Song, K., Osborn, T. C., and Williams, P. H. 1991. Relationship between pathogenicity and phylogeny based on restriction fragment length polymorphism in Leptosphaeria maculans. Mol. Plant-Microbe Interact. 4:341-349.

28. Majer, D., Lewis, B. G., and Mithen, R. 1998. Genetic variation among field isolates of Pyrenopeziza brassicae. Plant Pathol. 47:22-28.

29. Majer, D., Mithen, R., Lewis, B. G., Vos, P., and Oliver, R. P. 1996. The use of AFLP fingerprinting for the detection of genetic variation in fungi. Mycol. Res. 100:1107-1111.

30. McKemy, J. M., Glawe, D. A., and Munkvold, G. P. 1993. A hyphomycetous synanamorph of Eutypa armeniacae in artificial culture. Mycologia 85: 941-944.

31. Moller, W. J., and Kasimatis, A. N. 1978. Dieback of grapevines caused by Eutypa armeniacae. Plant Dis. Rep. 62:254-258.

32. Moller, W. J., and Kasimatis, A. N. 1981. Further evidence that Eutypa armeniacae - not Phomopsis viticola - incites dead arm symptoms on grape. Plant Dis. 65:429-431.

33. Moller, W. J., Ramos, D. E., and Carter, M. V. 1981. A comparison in virulence of Californian and Australian strains of the apricot dieback fungus, Eutypa armeniacae. Acta Hortic. 85:269-272.

34. Morales, V. M., Pelcher, L. E., and Taylor, J. L. 1993. Comparison of the 5.8s rDNA and internal transcribed spacer sequences of isolates of Leptosphaeria maculans from different pathogenicity groups. Curr. Genet. 23:490-495.

35. Munkvold, G. P., Duthie, A., and Marois, J. J. 1994. Reductions in yield and vegetative growth of grapevines due to Eutypa dieback. Phytopathology 84:186-192.

36. Munkvold, G. P., and Marois, J. J. 1993. The effects of fungicides on Eutypa lata germination, growth, and infection of grapevines. Plant Dis. 77:50-55.

37. Munkvold, G. P., and Marois, J. J. 1993. Efficacy of natural epiphytes and colonizers of grapevine pruning wounds for biological control of Eutypa dieback. Phytopathology 83:624-629.

38. Munkvold, G. P., and Marois, J. J. 1994. Eutypa dieback of sweet cherry and occurrence of Eutypa lata perithecia in the central valley of California. Plant. Dis. 78:200-207.

39. Munkvold, G. P., and Marois, J. J. 1995. Factors associated with variation in susceptibility of grapevine pruning wounds to infection by Eutypa lata. Phytopathology 85:249-256.

40. O'Donnell, K. 1992. Ribosomal DNA internal transcribed spacers are highly divergent in the phytopathogenic ascomycete Fusarium sambucinum (Gibberella pulicaris). Curr. Genet. 22:213-220.

41. O’Neill, N. R., van Berkum, P., Lin, J.-J., Kuo, J., Ude, G. N., Kenworthy, W., and Saunders, J. A. 1997. Application of amplified restriction fragment length polymorphism for genetic characterization of Colletotrichum pathogens of alfalfa. Phytopathology 87:745-750.

42. Péros, J. P., and Berger, G. 1994. A rapid method to assess the aggressiveness of Eutypa lata isolates and the susceptibility of grapevine cul- tivars to Eutypa dieback. Agronomie 14:515-523.

43. Péros, J. P., Berger, G., and Lahogue, F. 1997. Variation in pathogenicity and genetic structure in the Eutypa lata population of a single vineyard. Phytopathology 87:799-806.

44. Péros, J. P., This, P., Confuron, Y., and Chacon, H. 1996. Comparison by isozyme and RAPD analysis of some isolates of the grapevine dieback fungus, Eutypa lata. Am. J. Enol. Vitic. 47:49-56.

45. Petzoldt, C. H., Moller, W. J., and Sall, M. A. 1981. Eutypa dieback of grapevine: Seasonal differences in infection and duration of susceptibility of pruning wounds. Phytopathology 71:540-543.

46. Rappaz, F. 1987. Taxonomie et nomenclature des Diatrypacées à asques octospores. Mycol. Helv. 2:285-648.

47. Rehner, S. A., and Uecker, F. A. 1994. Nuclear ribosomal internal transcribed spacer phylogeny and host diversity in the coelomycete Phomopsis. Can. J. Bot. 72:1666-1674.

48. Russo, C. A. M., Takezaki, N., and Nei, M. 1996. Efficiencies of different genes and different tree-building methods in recovering a known vertebrate phylogeny. Mol. Biol. Evol. 13:525-536.

49. Saitou, N., and Nei, M. 1987. The neighbor-joining method: A new method for reconstructing phylogenetic trees. Mol. Biol. Evol. 4:406-425.

50. Schardl, C. L., Liu, J.-S., White, J. F., Jr., Finkel, R. A., An, Z., and Siegel, M. R. 1991. Molecular phylogenetic relationships of nonpathogenic grass mycosymbionts and clavicipitaceous plant pathogens. Plant Syst. Evol. 178:27-41.

51. Sicard, D., Michalakis, Y., Dron, M., and Neema, C. 1997. Genetic diversity and pathogenic variation of Colletotrichum lindemuthianum in the three centers of diversity of its host, Phaseolus vulgaris. Phytopathology 87:807-813.

52. Tamura, K., and Nei, M. 1993. Estimation of the number of nucleotide substitutions in the control region of mitochondrial DNA in humans and chimpanzees. Mol. Biol. Evol. 10:512-526.

53. Thompson, J. D., Higgins, D. G., and Gibson, T. J. 1994. CLUSTAL W: Improving the sensitivity of progressive multiple sequence alignment through sequence weighting, position-specific gap penalties and weight matrix choice. Nucleic Acids Res. 22:4673-4680.

54. Trese, A. T., Burton, C. L., and Ramsdell, D. C. 1980. Eutypa armeniacae in Michigan vineyards: Ascospore production and survival, host infection, and fungal growth at low temperatures. Phytopathology 70:788-793.

55. Ueng, P. P., Berstrom, G. C., Slay, R. M., Geiger, E. A., Shaner, G., and Scharen, A. L. 1992. Restriction fragment length polymorphisms in the wheat glume blotch fungus, Phaeosphaeria nodorum. Phytopathology 82:1302-1304.

56. Vos, P., Hogers, R., Bleeker, M., Reijans, M., van de Lee, T., Hornes, M., Frijters, A., Pot, J., Peleman, J., Kuiper, M., and Zabeau, M. 1995. AFLP: A new technique for DNA fingerprinting. Nucleic Acids Res. 23:4407-4414

57. Whisson, S. C., Maclean, D. J., Manners, J. M., and Irwin, A. G. 1992. Genetic relationships among Australian and North American isolates of Phytophthora megasperma f. sp. glycinea assessed by multicopy DNA probes. Phytopathology 82:863-868.

58. White, T. J., Bruns, T., Lee, S., and Taylor, J. 1990. Amplification and direct sequencing of fungal ribosomal RNA genes for phylogenetics. Pages 315322 in: PCR Protocols. M. Innis, D. H. Gelfand, J. J. Sninsky, and T. J. White, eds. Academic Press, San Diego, CA.

59. Williams, J. G. K., Kubelik, A., Livak, K., Rafalski, J. A., and Tingey, S. V. 1990. DNA polymorphisms amplified by arbitrary primers are useful as genetic markers. Nucleic Acids Res. 18:6531-6535.

60. Zambino, P. J., and Harrington, T. C. 1989. Isozyme variation within and among host-specialized varieties of Leptographium wageneri. Mycologia $81: 122-133$ 